\title{
An evaluation of the efficacy of extracts from Xylopia aethiopica and Dennittia tripetala in controlling Dermestes maculatus(degeer) an insect pest of dry stored fish in Calabar, Nigeria
}

\begin{abstract}
Laboratory bioassays were conducted in Obudu, Nigeria to evaluate the efficacy of extracts from X.aethiopica and D.tripetala in controlling D.maculatus a primary pest of dry stored fish in sub-saharan Africa. Adult population of D. maculatus was obtained in the laboratory at the Federal college of Education Obudu, to obtain fresh insects for the experimental work. Dried fruits of X.aethiopica (Dunal) and dried seeds of D.tripetala (Bak.f.) were procured from a local market in Obudu for the purpose of the work. $100 \mathrm{~g}$ each of the spice plants were pounded separately using laboratory pestle and mortar for the extraction of essential oils (EOS). The essential oils extracted were tested for repellence and toxicity against D.maculatus at $10 \mu \mathrm{l}$ per EO in a 4 -way Olfactometer. Minitab 15 statistical soft ware was used for the analysis of data. Results indicated that the essential oils (EOS) and their constituent individual compounds were significantly $(\mathrm{p}<0.05)$ repellent and toxic to D.maculatus with X.aethiopica more repellent and more toxic to the insect than D.tripelala. The two oils were also observed to inhibit the activities of microbes that usually cause and accelerate delaying in stored fish. This action of the essential oils of the two spice plants and their chemical constituent demonstrated their potentials for development in stored products protection, especially at the small scale resource poor farmer's level in Nigeria.
\end{abstract}

Keywords: laboratory bioassay, efficacy, D.maculatus, repellency, toxicity, olfactounater, environment
Volume 10 Issue I - 202 I

\author{
Ugbe Lawrence A,' Agim Marcel,'Ada Fidelis \\ $\mathrm{B}^{2}$ \\ 'Department of Agriculture, Federal College of Education \\ Obudu, Nigeria \\ ${ }^{2}$ Department of Fisheries and Aquatic Science, Cross River \\ University of Technology, Nigeria
}

Correspondence: Fidelis Bekeh Ada, Department of Fisheries and Aquatic Science, Cross River University of Technology, Nigeria,Tel +2348068546835, Email fbekehada@yahoo.com

Received: November 22, 2020 | Published: January 28, 2021

\section{Introduction}

Fish is a major source of protein and its harvesting, handling, processing and distribution provides livelihood for millions of people as well as providing foreign exchange earning to many countries. ${ }^{1}$ However, it is said that appropriate processing of fish enables maximum use of raw material and production of value -added products which is obviously the basis of processing profitability. ${ }^{2}$

Fish is not only a good source of protein but also contains some useful amino-acids, vitamins, minerals and poly-unsaturated fatty acids not found in other sources of fat from aquatic environment. ${ }^{2}$ Fish production system in Nigeria is mainly artisanal, and fish are marketed mostly in five different forms; fresh, smoked, dried, salted and frozen. ${ }^{3}$ As aquaculture development is fast gathering momentum in Nigeria, it has been observed that processing of fish by smoking, sun drying or salting are still widely use for fish preservation in Nigeria. In fact, many fish species in Nigeria have good preservation qualities after salting, sun drying and even smoking. ${ }^{4}$ Poor fish preservation, leads to fish loss at storage. Fish losses at storage due to poor processing is a major impediment to the realization of government goal toward increasing the contribution of the sector to the overall national economy. ${ }^{1}$ Even well processed and dried fish at storage is being attached by several other living organisms ranging from micro-organism to storage insect pests. According to Ayaba and Omeji ${ }^{5}$ insect infestation is the cause of most prominent loses in quality and quantity of stored fish in Nigeria.

Much of stored grains as well as stored meat and fish are often grains damaged by insect pests that infest them. Several figures have been estimated in literatures on the extent of stored products (grains, meat and fish) damage resulting from insect pests attacks. Example, Holst, Meckel, and Markhan ${ }^{6}$ reported about $30-40 \%$ losses of stored products arising from insect pests in the tropics and 25 to $30 \%$ in West Africa. Stored products of animal origin such as meat, hides, and fish, particularly fish are usually attached by the insect called Dermestes maculatus (Degeer).

\section{Identification of Dermestes maculatus(Degeer)}

The body of adult is sub parcelled and $6-10 \mathrm{~mm}$ long with a dark brown or black cuticle. Dorsally, the body is clothed in black and greyish hairs. The later are denser around the lateral margins of the pronotum. Ventrally, the abdomen is thickly covered in white hairs with patches of black hairs laterally and apically. In the centre of the 4 th sternite of the male, there is a hairy pit. The antennae are eleven segmented and have a distinct three-segmented club. The inner apex of each elytron is produced to form an acute spine, this feature is useful in distinguishing D. maculatus from $D$. frischii. ${ }^{7}$

The first instar larvae measure about $1.5 \mathrm{~mm}$, the mature larvae are about $15 \mathrm{~mm}$ long. They are very hairy and have dark brown tergites between which lie cream - coloured inter segmental membrane. A Dull orange medium stripe is present and at the posterior end, there are two anteriorly curved urogomph. The ventral surface is cream colured and possesses shorthairs. ${ }^{8}$

\section{Brief life History of D. maculatus}

The larvae and to a lesser extent, the adult of D. maculatus feed on animal material, especially hides and dried fish. Infestation of fish can start in the early stages of drying. Observations suggest that the fish 
needs to be at least surface dried before egg-laying commerces. ${ }^{8}$ There appears to be some variability in the susceptibility of different fish genera, eg Clarias and Tilapia are easily infested whereas, Hydrocym and synodontis are some what more resistant. ${ }^{8}$ Fish of freshwater origin are more frequently attacked by $D$. maculatus. This is probably due to the rather low salt tolerance of this species. Development of the larvae is apparently impossible on fish meal with a salt level as high as $10 \%$.?

Within 12-40 hours of copulation, females lay eggs (1.3mm long and $0.35 \mathrm{~mm}$ diameter). For regular ovi position, the females must be able to drink water under laboratory conditions, and they lay on average 17 eggs per day. ${ }^{8}$ Larval development is affected by both temperature and humidity. At 21, 27 and $35^{\circ} \mathrm{C}(75 \%$ r.h $)$ development lasts on average 53,28 , and 70 days respectively while at $27^{\circ} \mathrm{C}$ with the lower r.h of $53 \%$ the period is increased to 35 days. ${ }^{9}$ The number of larval instars is variable, the member is lowest under favourable conditions, being on average 6-7 but as many as 11 instars have been recorded. The larvae are cannibalistic, attacking eggs and pupae.?

Fish farmers and fish traders in Nigeria have been facing problems of fish deterioration and spoilage during storage. Worst is the attack by storage insect pests. In the age long preservation method, salt in greater quantity has been used to preserve fish and prevent microbial infestation. For instance, Omojowo reported that $5 \%$ sodium chloride (salt) may be used as a preservative in smoked fish without adversely affecting the fish quality in terms of colour and organoleptic quality for a period up to six weeks. However, salting of fish in greater quantity to check the activities of microbes make it medically unfit by patience of hypertension and diabetes. Moreover the salting of fish does not stop stored insect pests from attacking the fish. In view of this, fish dealers now resort to the use of dangerous chemicals such as snippers (DDT compound) to check the activities of insect pests in stored fish. This is detrimental to the health of consumers of the fish. It is on the basis of this ugly development, that this research was carried out to test the efficacy of plant extracts in controlling Dermestes maculatusa primary pest of stored fish in Nigeria, as a substitute to the use of dangerous chemicals in protecting the insect pests from stored fish.

\section{Materials and methods}

\section{Insect culture and the collection of materials}

Inoculum of $D$. maculates was collected form infested fish in a fish shop in Obudu Main Market situated in Northern Senatorial Zone of Cross River State. The inoculums was added to dry mud fish, Clarias species obtained from River Benue in Benue State of Nigeria and kept at room temperature Usuji, 1975 in a laboratory in the Department of Agricultural Education Federal College of Education Obudu, Cross River State Nigeria where the bioassay experiments were conducted. After six weeks, the insect population in the infested fish were sieved out of the fish, with a filter of mesh size $1.2 \mathrm{~cm}$. Ayotunde et al. 2016 carried out qualitative analysis of insect pest and used dissection of stored fish to remove and identify the insects. Some quantity of ripe and fresh fruits of Xylopia aethiopica and Dennettia tripelala were procured from a local market in Obudu Local Government Area for the purpose of the bioassay experiments, the fruits were washed and sun dried.

\section{Extraction of the essential oils (EOs) from X.aethiopica and D.tripetala}

One hundred gram $(100 \mathrm{~g})$ each of dried fruits of D. tripetala and $X$. aethiopica were separately grounded into powder, using laboratory pestle and mortar. The powdered D. Tripetala was dissolved in a $50 \mathrm{ml}$ of redistilled diethyl ether. The container was immersed in an ultrasonic wave-device for 5 minutes to disperse and homogenize the contents. The vacuum distillation apparatus was then connected to a high vacuum pump (ES50 Vacuum Pump. Edwards, England). The glass sections of the apparatus were strongly heated with a hot air blower to remove any less volatile contaminants from its internal surface. The tube shaped in U-form and the pear shaped vessel meant for the collection of the distillate was submerged completely in Nitrogen at a temperature of $-196^{\circ} \mathrm{c}$. The residue extracted was then distilled for 24 hours at a pressure of $0.05 \mathrm{mmHg} . X$. aethiopica powder was vacuum distilled in a similar manner as explained above. The ether distillates of these substances were then pipetted from the vacuum distillation apparatus through long drawn Pasteur pipette into $50 \mathrm{ml}$ separation funnels to remove water. The extracts were dried using magnesium sulphate $\left(\mathrm{MgSO}_{4}\right)$, then filtered and concentrated in order to obtain $4 \mathrm{ml}$ each of $D$. tripetala and X. aethiopica essential oils (EOs). Each of the vacuum distilled extract was sealed under nitrogen, labelled accordingly and placed in different ampoules, pending when they were used for the laboratory Olfactomater bioassay.

\section{Laboratory bioassay with the essential oils (EOs)}

Essential Oils extracted from D.tripetala and X.aethiopica were each impregnated into filter paper and placed alongside with a piece of dried fish in one arm of Olfactometer, while the other three arms were reserved as control. An Olfactometer consists of a $6 \mathrm{~mm}$ thick transparent Perspex held together. A four pointed exposure chamber shaped like a star is fixed to a circular plate measuring $12 \mathrm{~cm} \times 12 \mathrm{~cm}$ with a hole $(3 \mathrm{~mm})$ drilled into the walls at each point of the four cardinal glass frames. Another plate $10.2 \mathrm{~cm} \times 10.2 \mathrm{~cm}$ with a hole of $4 \mathrm{~mm}$ in diameter at the centre is used as a cover. In order for the insect pest to work easily in the Olfactomer, a sheet of fisher brand QL 100 filter paper (spring field mill, Maidstone, Kent England) was placed on the floor as covering. An air stream was passed into the Olfactometer through a Telfon tubing of size $3.2 \mathrm{~mm}$ (Cam/ab/Ltd.Uk) from an Air entrainment chamber to keep the insect mobile. ${ }^{9}$

In the bioassay experiment involving the insect pest and the essential oils from the two spice plants, the parameters assessed, were the time spent by the insect (D. maculatus) in the different arms of the Olfactometer and the number of times the insect visited the different odour zones. All treatments were replicated ten (10) times on twelve minutes duration using a three day old insect (D. maculatus). A fresh (3 day old) insect (D. maculatus) and a fresh stimulus source were used in each single choice test.

\section{Data Analysis}

All data generated were subjected to analysis of variance (ANOVA) procedure and means were compared using Tukey's Simultaneous means separation, according to Zar, ${ }^{10}$ or least significant difference (LSD) at 0.05 level of probability. Data on the number of entries or visits made by the insect to the test arm and control were analysed using t-test at (0.05) level of probability. Minitab 15 statistical soft ware was used for the analysis of data.

\section{Results}

The essential oils (EOs) extracted from the two spice plants were tested individually for bioactivity against the insect pest $(D$. maculatus) of dry stored fish. The time spent by the insect in the test arm containing a piece of dry fish plus essential oils from $D$. tripetala and X. aethiopica, impregnated separately in filter paper was 
significantly $(\mathrm{p}<0.05)$ different compared to, on separate occasions with the time spent in the control arms (Table 1a).

Table I Behavioural responses of D. Maculates to volatiles from a piece of dry fish plus essential oils (EOs) of D.tripetala and X.aethiopica Mean time spent by the insect (Minute \pm SE)

\begin{tabular}{lll}
\hline Treatments & D.tripetala & X.aethiopica \\
\hline Test Arm & 0.622 & 1.356 \\
Control I & 3.045 & 3.372 \\
Control 2 & 2.342 & 3.422 \\
Control 3 & 2.377 & 3.653 \\
X & 2.096 & 2.95 \\
SEM \pm & 0.276 & 0.632 \\
CV\% & 21.35 & 22.21 \\
LSD (0.05) & 0.533 & 0.621 \\
\hline
\end{tabular}

The number of visits made by the insect to the test arm containing a piece of dry fish and filter papers separately impregnated with essential oils from D.tripetala and X. Aethiopica was significantly $(\mathrm{p}<0.05)$ different compared to the number of entries to the control arms (Table 1b).

Table I b Mean number of entries into each arm of the olfactometer

\begin{tabular}{lll}
\hline Treatments & D.tripetala & X.aethiopica \\
\hline Test Arm & $0.624 \pm 0.21 \mathrm{I} .823 \pm 0.31$ \\
Control & $6.381 \pm 0.233 .026 \pm 0.26$ \\
$\mathrm{X}$ & $3.503 \pm 0.22$ & $2.425 \pm 0.44$ \\
$\mathrm{t}(0.05) 0.22^{*}$ & $0.66^{*}$ &
\end{tabular}

*Significant at $(\mathrm{p}<0.05)$ level of probability

The number of visits made by the insect to the test arm containing a piece of dry fish and filter papers separately impregnated with essential oils from D.tripetala and X. Aethiopica was significantly $(p<0.05)$ different compared to the number of entries to the control arms (Table 1b)

Table 2 Behavioural responses of D.maculatus to volatiles from a piece of dry fish plus $10 \mu \mathrm{l}$ vacuum distilled hexane fraction of D.tripatala and X.aethiopica in an Olfactometer

(a)Mean time spent by the insect (Minutes \pm SE)

\begin{tabular}{lll}
\hline Treatments & D.tripetala & X.aethiopica \\
\hline Test Arm & 0.622 & 1.52 \\
Control I & 3.712 & $3.81 \mathrm{I}$ \\
Control 2 & 3.068 & 3.472 \\
Control 3 & $2.85 \mathrm{I}$ & 3.522 \\
X & 2.572 & $3.08 \mathrm{I}$ \\
SEM \pm & 0.168 & 1.352 \\
CV\% & 22.9 & 12.23 \\
LSD $(0.05)$ & NS & NS \\
\hline
\end{tabular}

NS, Not Significant at $(p>0.05)$ level of probability

The number of visits or entries by the insect to the test arm containing a piece of dry fish plus vacuum distilled hexane fractions of $D$.tripetala and $X$. aethiopica was also not significantly $(\mathrm{p}>0.05)$ different compared to the number of entries into the control arms (Table 2b)

Table 2b Mean number of entries into each arm of the olfactometer

\begin{tabular}{lll}
\hline Treatments & D.tripetala & X.aethiopica \\
\hline Test Arm & $1.702 \pm 0.22$ & $2.820 \pm 0.32$ \\
Control & $4.463 \pm 0.31$ & $3.520 \pm 0.26$ \\
X & $3.083 \pm 0.263$ & $17 \pm 0.29$ \\
$t(0.05) N S N S$ & &
\end{tabular}

NS, Not Significant at $(p<0.05)$ level of probability

The time spent by D. maculatus in the test arm of Olfactometer containing on separate occasions a piece of dry fish plus vacuum distilled diethyl ether fractions of $D$. tripetala and $X$. aethiopica impregnated in filter paper separately, was significantly $(p<0.05)$ different, compared to the time spent by the insect in the control arms (Table 3a).

Table 3 Behavioural responses of D.maculatus to volatiles from a piece of dry fish plus $10 \mu \mathrm{l}$ vacuum distilled diethyl ether fractions of D.tripetala and $X$.aethiopica in an Olfactometer

(a)Mean time spent by the insect (Minutes $\pm \mathrm{SE}$ )

\begin{tabular}{cll}
\hline Treatments & D.tripetala & X.aethiopica \\
\hline Test Arm & 1.204 & 1.277 \\
Control I & 3.2162 .163 & \\
Control 2 & 3.0442 .472 & \\
Control 3 & $3.28 \mathrm{I}$ & $2.65 \mathrm{I}$ \\
$\mathrm{X}$ & 2.686 & $2.14 \mathrm{I}$ \\
SEM \pm & $2.5220 .26 \mathrm{I}$ & \\
CV\% & 22.4226 .80 & \\
LSD $(0.05)$ & 0.5240 .635 & \\
\hline
\end{tabular}

Similarly, the number of entries or visits by the insect to the test arms containing a piece of fish plus vacuum distilled diethyl other fractions of $D$. tripetala and X. Aethiopica on separate occasions, was significantly $(p<0.05)$ different, compared to the number of entries or visits by the insect to the control arms (Table $3 \mathrm{~b}$ ). The result of the bioassay experiment involving the chemical components of $D$. tripetals essential oil showed that the time spent by $D$. maculatus in the text arm containing a piece of dry fish and the chemical components each impregnated in filter paper at separate occasions, was significantly $(\mathrm{p}<0.05)$ different compared to the time spent by the insect in the control arms of the Olfactometer (Table 4a).

Table 3b Mean number of entries into each arm of the olfactometer

\begin{tabular}{lll}
\hline Treatments & D.tripetala & X.aethiopica \\
\hline Test Arm & $1.892 \pm 0.0 .05$ & $4.826 \pm 0.23$ \\
Control & $3.863 \pm 0.32$ & $5.071 \pm 0.33$ \\
$X$ & $2.877 \pm 0.20$ & $4.950 \pm 0.28$ \\
$\mathrm{t}(0.05)$ & $1.85^{*}$ & $2.64 *$ \\
\hline
\end{tabular}

*Significant at $(p<0.05)$ level of probability 
Table 4 Behavioural responses of $D$. maculatus to volatiles from a piece of dry fish plus I0 $\mu$ l chemical components of diethyl ether of $D$.tripatala in Olfactometer (a) Mean time spent by the insect (Minutes $\pm \mathrm{SE}$ ).

\begin{tabular}{|c|c|c|c|c|}
\hline Treatments & I,3-cyclopentadien & $(0.3 \mathrm{mg} / \mathrm{ml})$ & I,6-cyclodecadien $(0.5 \mathrm{mg} / \mathrm{ml})$ & 2-undecene $(0.2 \mathrm{mg} / \mathrm{ml})$ \\
\hline Test Arm & $1.23 \pm 0.21$ & & $1.62 \pm 0.20$ & $1.25 \pm 0.22$ \\
\hline Control I & $2.36 \pm 0.22$ & & $2.65 \pm 0.26$ & $2.53 \pm 0.18$ \\
\hline Control 2 & $3.06 \pm 0.20$ & & $2.45 \pm 0.23$ & $3.0 \mathrm{I} \pm 0.25$ \\
\hline Control 3 & $2.8 I \pm 0.23$ & & $2.46 \pm 0.22$ & $2.85 \pm 0.23$ \\
\hline$x$ & $2.36 \pm 0.22$ & & $2.30 \pm 0.23$ & $2.4 I \pm 0.22$ \\
\hline SEM \pm & 0.1760 .533 & & & 0.16 \\
\hline $\mathrm{CV} \%$ & 22.8521 .85 & & & 20.2 \\
\hline LSD (0.05) & 0.5330 .582 & & & 0.473 \\
\hline
\end{tabular}

Similarly, the number of entries or visits made by the insect to the test arm containing the different extracts of diethyl ether of $D$. tripetala, on separate occasions was significantly $(\mathrm{P}<0.05)$ different compared to the number of entries or visits to the control arms of the Olfactometer (Table 4b).

The result of the experiment involving chemical constituents of diethyl ether from $X$. aethiopica also showed that the time spent by the insect (D. maculatus) in the test arm containing a piece of dry fish plus the chemical constituents was on different occasions significantly $(p<0.05)$ different when compared to the time spent by the insect in the three control arms (Table 5a).

In the same manner, the number of entries or visits made by the insect to the test arm containing piece of dry fish plus the different chemical constituents of the diethyl ether of X. aethiopica on separate occasions, was significantly $(\mathrm{p}<0.05)$ different compared to the number of visits to the control arms of the Olfactometer (Table $5 b$ )

Table 4bMean number of entries into each of the Olfactomoter

\begin{tabular}{|c|c|c|c|c|}
\hline Treatments & I,3-cyclopentadien & $(0.3 \mathrm{mg} / \mathrm{ml})$ & I,6-cyclodecadien $(0.5$ mg/ml) & 2-undecene $(0.2 \mathrm{mg} / \mathrm{ml})$ \\
\hline Test Arm & $1.22 \pm 0.222$ & & $.02 \pm 0$ & $1.22 \pm 0.23$ \\
\hline Control & $6.23 \pm 0.235$ & & $80 \pm 0.227$ & $1.22 \pm 0.23$ \\
\hline$x$ & $3.73 \pm 0.233$ & & $91 \pm 0.23$ & $4.23 \pm 0.24$ \\
\hline \multicolumn{5}{|c|}{$\mathrm{t}(0.05) 0.66 * 0.54 * 0.63 *$} \\
\hline
\end{tabular}

*Significant at $(p<0.05)$ level of probability

Table 5 Behavioural responses of $D$. maculatus to volatiles from a piece of dry fish plus $10 \mu$ l vacuum distilled chemical constituents of diethyl ether of X.aethiopica in Olfactometer

(a) Mean time spent by the insect (Minutes \pm SE)

\begin{tabular}{llll}
\hline Treatments & $\mathbf{I}, \mathbf{8}$ cineole $(\mathbf{0 . 3} \mathbf{~ m g} / \mathbf{m l})$ & b-Phellandrene $(\mathbf{0 . 4 m g} / \mathbf{m l})$ & b-Pinene $(\mathbf{0 . 3} \mathbf{m g} / \mathbf{m l})$ \\
\hline Test Arm & $1.52 \pm 0.22$ & $1.66 \pm 0.24$ & $1.65 \pm 0.20$ \\
Control I & $2.43 \pm 0.21$ & $2.44 \pm 0.21$ & $2.76 \pm 0.22$ \\
Control 2 & $3.51 \pm 0.30$ & $2.78 \pm 0.22$ & $2.66 \pm 0.31$ \\
Control 3 & $3.22 \pm 0.25$ & $2.56 \pm 0.24$ & $2.71 \pm 0.30$ \\
$\quad \mathbf{X}$ & $2.67 \pm 0.25$ & $2.36 \pm 0.23$ & $2.45 \pm 0.25$ \\
SEM \pm & 0.582 & 0.201 & 0.655 \\
CV\% & 18.36 & 25.40 & 22.40 \\
LSD $(0.05)$ & 0.538 & 0.562 & 0.264 \\
\hline
\end{tabular}

Table 5b Mean number of entries into each arm of the Olfactomoter

\begin{tabular}{llll}
\hline Treatments & $\mathbf{I}, \mathbf{8}$ cineole $(\mathbf{0 . 3} \mathbf{~} \mathbf{m g} / \mathbf{m l})$ & b-Phellandrene $(\mathbf{0 . 4} \mathbf{m g} / \mathbf{m l})$ & b-Pinene $(\mathbf{0 . 3} \mathbf{m g} / \mathbf{m l})$ \\
\hline Test Arm & $1.45 \pm 0.22$ & $1.95 \pm 0.22$ & $1.90 \pm 0.26$ \\
Control & $6.55 \pm 0.21$ & $6.73 \pm 0.32$ & $4.56 \pm 0.22$ \\
$\mathbf{X}$ & $4.00 \pm 0.22$ & $4.34 \pm 0.27$ & $3.23 \pm 0.24$ \\
$\mathrm{t}(0.05)$ & $\mathbf{0 . 6 3 1 * 0 . 8 2 2 *}$ & $0.750 *$ & \\
\hline
\end{tabular}

*Significant at $(\mathrm{p}<0.05)$ level of probability 


\section{Comparing the efficacy of the essential oils from the two spice plants in repelling D. maculatus from the dry fish}

In comparing the efficacy of the essential oils from the two spice plants ( $X$. aethiopica and D. tripetala in repelling D. maculatus from dry fish, $10 \mu 1$ of each essential oil was applied separately on two dry, weighed, and partially rotten or decomposing fish. One fish (untreated) was left as control, the three fish placed inside wire net to prevent flies from perching were kept at room temperature in the laboratory for up to ten weeks. The fish were inspected physically on weekly basis for $D$. maculatus attack. They were also weighed separately every week to determine the percentage weight loss resulting from deterioration or rotting. The percentage weight loss was calculated using the formula:

$$
\frac{\text { Initial weight }- \text { current weight }}{\text { Initial weight }} \times 100 \mathrm{~g}
$$

Table 6 Bioactivity of the essential oils of the two spice plants (X.aethiopica and D.tripetala) on D.maculatus attack on fish and fish deterioration

\begin{tabular}{llll}
\hline $\begin{array}{l}\text { No. of } \\
\text { weeks }\end{array}$ & $\begin{array}{l}\text { EOs of } \\
\text { D.tripetala } \\
\text { Weight loss } \mathbf{( g )}\end{array}$ & $\begin{array}{l}\text { EOs of } \\
\text { X.aethiopica } \\
\text { Weight loss } \mathbf{( g )}\end{array}$ & $\begin{array}{l}\text { Control } \\
\text { Weight loss } \mathbf{( g )}\end{array}$ \\
\hline 1 & 40 & 42 & 45 \\
2 & 34 & 40 & 40 \\
3 & 30 & 39 & 37 \\
4 & 28 & 37 & 33 \\
5 & 25 & 34 & 28 \\
6 & 22 & 32 & 18 \\
7 & 20 & 31 & 15 \\
8 & 18 & 30 & 12 \\
9 & 16 & 28 & 8 \\
10 & 13 & 26 & 5 \\
\hline
\end{tabular}

The rate of weight loss during the period of fish deterioration is shown on the bar charts below: (Figure 1)

\section{Discussion}

Insects frequently locate their food source/host through the detection of volatile chemical cues emanating from the source through olfactory receptors situated on the antenna. ${ }^{11}$ This means that insect species are able to detect a suitable host while working or during flight, and also host selection can depend on a lack of repellent odour. D. maculatus responded positively towards air plumes that emanated from the piece of dry fish and negatively to the ones from the essential oils of the two spice plants (X. aethiopica and D. tripetala). The positive response of the insect to volatiles from dry fish proved that it was able to identify its food source by perceiving the odour emitted from the dry fish with the help of its antennae. This result is in agreement with Pike et al. ${ }^{12}$ who reported that $S$. zeamais was attracted to maize volatile; also Mound ${ }^{8}$ reported that fish meal attracts Dermestes maculatus. The different volatile aroma compounds from rice flavour types have also been reported by Yang et al. ${ }^{13}$

The volatile aroma compounds from the spice plants are commonly use domestically to flavour foods and in the industries to manufacture perfumes. ${ }^{14}$ The essential oils from these aromatic plants are said to consist of complex mixture of monoterpenes, diterpenes, triterpenes and sesquiterpenes hydrocarbons, aliphatic as well as aromatic compounds with a few major constituents. ${ }^{15}$ In an Olfactometer experiment conducted with vacuum distilled essential oils from $X$. aethropica and $D$. tripetala against $D$.maculatus, the insect was at separate times repelled by the aroma from the essential oils of the two spice plants. This result is in line with Ukeh ${ }^{9}$ who reported the repellence of $A$. melegueta and zingiber officinale against $S$. zeamais. There was no repellent effect against the insect (D. maculatus), when conducted with the non-polar hexane fraction of the essential oils from the two spice plants (Table 2). However, there was a repellent effect against the insect in the Olfactometer experiment conducted with the diethyl ether fraction of the essential oil (Table 3). It was therefore established that the repellence of the essential oil (EOs), was attributed to the polar florisil R diethyl ether component of the (EOs) rather than the non polar hexane component. The repellence test with the diethyl ether fractions against $D$. maculatus was significantly $(\mathrm{p}<0.05)$ different in respect to the mean time spent by the insect in the test arm and the control arms. The number of entries by the insect to the test arm was significantly less, compared to the number of entries to the control arms (Table 3). The isolation of the chemical components of the diethyl ether showed that $X$. aethiopica contains $0.3 \mathrm{mg} / \mathrm{ml} \quad 1,8$-cineole, $0.4 \mathrm{mg} / \mathrm{ml}$ b-phellandrene and $0.3 \mathrm{mg} / \mathrm{ml}$ b-pinene, while $D$. tripetala contains: $0.3 \mathrm{mg} / \mathrm{ml} \mathrm{1,3-cyclopentadien,}$ $0.5 \mathrm{mg} / \mathrm{ml} 1,6$-cyclodecadien and $0.2 \mathrm{mg} / \mathrm{ml} \mathrm{2-undecene.} \mathrm{All} \mathrm{the}$ isolated compounds of the two spice plants presented a significant $(\mathrm{p}<0.05)$ repellence and toxicity against the stored products insect pest (D.maculatus) (Tables 4 (a \& b), 5 (a \&b)). The isolation here was in line with Ajaiyeoba and Ekindayo ${ }^{15}$ who identified and isolated four aryldecanones and eight minor compounds from n-hexane and metabolic seed extract of A.melegueta obtained from south western Nigeria.
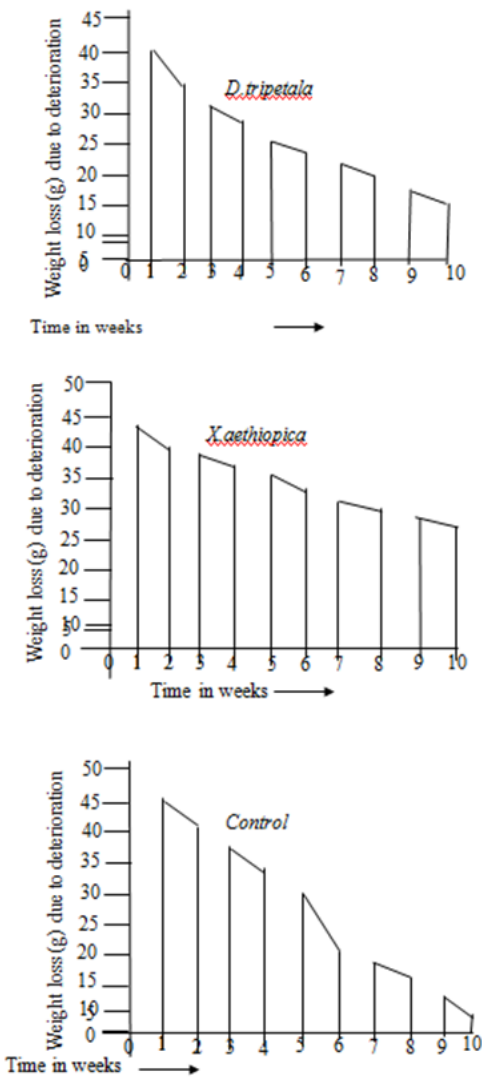

Figure I 
From the experiment conducted to compare the efficacies of the two spice plants in repelling $D$. maculates from the dry fish, it was observed that the insect pest (D. maculatus) was not found around the dry fish applied with the essential oils from the two spice plants $(X$. aethiopica and D. tripetala). However, some of the insects were found around the fish that was kept as control. Moreso, the decomposition rate of the two fish applied with the essential oils was significantly slowed down compared to the fish on control (Table 6). The slow decomposition rate was recorded more in the fish applied with EO from X. aethiopica than the one applied with EO from D. tripetale (see Bar Charts). It was therefore concluded from this experiment that the essential oils of the two spice plants $(X$. aethiopica and $D$. tripetala $)$ were not only capable of repelling the insect pest of dry fish (D. maculatus) but were capable of slowing down decomposition rate in fish by inhibiting the activities of microbes which cause deterioration in fish. This is in line with the report of Rosell et al. ${ }^{16}$ that extracts from many spice plants have the properties of insecticidal and anti-microbial and are good for post harvest protection of stored products.

\section{Conclusion}

To keep stored products (fish, meat, grains etc) free from the destructive effects of insect pests, is a common practice in several countries of the world. ${ }^{11}$ However, there is a great need to replace the use of synthetic pesticides in preserving fish. The current ugly trend whereby people use poisonous snipper (DDT derivative ) to preserve fish, must stop and be replaced with the use of biopesticides. The option of replacing the toxic synthetic pesticides with plant base pesticides, at a time when there are heightened public concerns over the hazardous effect of the synthetic pesticides is now receiving serious attention amongst scientists the world over. The result of the laboratory experiments conducted here showed that the diethyl ether fractions from the essential oils of $X$. aethiopica and D. tripetala have significant capacity for bioactivity against Dermestes maculatus. Identifying and testing the repellent and toxic effect of the chemical constituents of the EOs from the two spice plants here, may provide further opportunities for their use in post harvest crop protection, ${ }^{9}$ especially by the resource poor small scale farmers in traditional African setting.

\section{Recommendations}

This research work recommends the use of essential oil extracts from X.aethiopica and D.tripetala by fish farmers and dealers in preserving dry fish and stock fish rather than using the poisonous synthetic pesticides such as Snipper, Gamaline, Atellic etc. The Government should encourage local farmers to engage in massive production of these spice plants to make them available and cheap.. The necessary machines and equipment needed for the extraction of the essential oils (EOs) from these spice plants should also be made available in local communities where farmers can extract the oils at cheaper cost for use by fish farmers and dealers.

\section{Conflict of interest}

The author declares no conflict of interest.

\section{Acknowledgments}

None.

\section{Funding}

None.

\section{References}

1. Al-Jufaili MS, Opara LU. Status of Fisheries postharvest industry in the sultanate of Oman: Part 1 handling and marketing system of fresh fish. Journal of Fisheries International. 2006;1(2):144-149.

2. Tawari CC, Abowei JFN. Traditional Fish handling and Preservation in Nigeria. Asian Journal of Agricultural Science. 2011;3(6):427-436.

3. FAO. Fisheries and aquaculture in sub-Saharan Africa: Situation and outlook in 1996, FAO Fisheries circular No. 922, FAO, Rome.1996;1 -44 .

4. Singh RP, Heldman DR. Introduction to Food Engineering. 5th ed, New Delhi: Academic Press. 2013.

5. Ayuba VO, Omeji NO. Effect of insect infestation on the shelf life of smoked dried fish. Proceedings of the 21st Annual Conference of the Fisheries society of Nigeria (FISON). 2007;369-372.

6. Holst N, Meikle WS, Markham RH. Grain injury models for Prostepharus truncatus (Coleoptera: Bostrichidae) and Sitophilus zeamais (Colaeptera: Curculionodae) in rural maize stores in West Africa. J Econ Entomol. 2000;93(4):1338-1346.

7. Coombs CW. The development, fecundity and longevity of Dermestes ater Degeer (Coleoptera: Dermestidae). Journal of Stored Products Research. 1981;17(1):31-36.

8. Mound L. Common insect pests of stored food products. Economic series, No. 15. 7th Edn. London: British Nuseum (Natural History) 1989.

9. Ukeh DA, Birkett MA, Bruce TJA, et al. Behavioural responses of the maize weevil, S. zeamais to host (maize grain) and non-host plant volatiles. Pest Management Science. 2010;66(1):44-50.

10. Zar JH. Biostatistical analysis. 4th edition, prentice Hall, upper saddle River, New Jersey. 1999

11. Duke SO, Baerson SR, Dayan FE, et al, United State Department of Agriculture, Agricultural Research Service, research on natural products for pest management. Pest Manag Sci. 2003;59(6-7):708 -717.

12. Pike V, Smith JL, White RD, et al. Studies of responses of stored products pests, Prostepharus truncatus (Horn) and Sitophilus zeamais (Motch), to food volatiles, In: Highley E, Wright EJ, Banks HJ, Champ BK editors. Proceedings of the 6th International working conference on stored products protection, Canbera, Australia. Walhinsford, Uk, CAB International. 1994; p. 566-569.

13. Yang DS, Shawfalt RL, Lee KS, et al. Comparism of odour of active compounds from six distinctly different rice flavour types. Journal of Agricultural and Food Chemistry. 2008;56:2780-2787.

14. Coppen JJW. Flavours and Fragrances of plant origin- Food and Agriculture Organisation (FAO) Report, 1995.

15. Ajaiyeoba EO, Ekundayo O. Essential oils constituents of Aframomum melegueta (Roscoe) K. Schum seeds (alligator pepper) from Nigeria. Flavour and Fragrance Journal.1999;14(2):109-111.

16. Rosell G, Quero C, Coll J, et al. Biorational Insecticides in pest management. Journal of Pesticide Science. 2008;33(2):103-121. 